\title{
Mineral chemistry of lava flows from Linga area of the Eastern Deccan Volcanic Province, India
}

\author{
Sohini Ganguly ${ }^{1, *}$, Jyotisankar Ray ${ }^{1}$, Christian Koeberl ${ }^{2}$, \\ Theodoros Ntaflos ${ }^{2}$ and Mousumi BanerJeE ${ }^{1}$ \\ ${ }^{1}$ Department of Geology, University of Calcutta, 35 Ballygunge Circular Road, Kolkata 700 019, India. \\ ${ }^{2}$ Department of Lithospheric Research, Center for Earth Sciences, University of Vienna, \\ Althanstrasse 14, A-1090 Vienna, Austria. \\ ${ }^{*}$ Corresponding author.e-mail: sganguly.geocal@gmail.com
}

\begin{abstract}
Several basaltic lava flows have been identified in the study area in and around Linga, in the Eastern Deccan Volcanic Province (EDVP) on the basis of distinctly developed structural zones defined by primary volcanic structures such as columnar joints and vesicles. These basaltic lava flows are spatially distributed in four different sectors, viz., (i) Bargona-Gadarwara (BG) sector (ii) Shikarpur-Linga (SL) sector (iii) Arjunvari-Survir Hill (AS) sector and (iv) Kukrachiman-Morand Hill (KM) sector. A threetier classification scheme has been adopted for the characterization and classification of individual lava flows. Each lava flow consists of a Lower Colonnade Zone (LCZ) overlain by the Entablature Zone (EZ) and Upper Colonnade Zone (UCZ). The LCZ and UCZ grade into a distinct/indistinct Lower Vesicular Zone (LVZ) and Upper Vesicular Zone (UVZ), respectively. The LCZ and UCZ of the flows are characterized by columnar joints while the EZ is marked by multi-directional hackly jointing. The geometry of different joint patterns corresponds to different styles of cooling during solidification of lava flows. Detailed petrographic studies of the investigated lava flows reveal inequigranular phenocrystal basalts characterized by development of phenocrystal phases including plagioclase, clinopyroxene and olivine, whereas groundmass composition is marked by tiny plagioclase, clinopyroxene, opaque mineral and glass. Electron microprobe analyses indicate that the olivine has a wide range $\sim \mathrm{Fo}_{22}$ to $\mathrm{Fo}_{66}$ revealing a wide spectrum of compositional variation. Pyroxene compositions are distinctly designated as Quad pyroxenes. Phenocrystal pyroxenes are mostly diopsidic, while the groundmass pyroxenes mainly correspond to augite with a minor pigeonite component. Pyroxene phenocrysts are characterized by a prominent Tienrichment. Phenocrystal plagioclase grains are calcic $\left(\mathrm{An}_{52.7}-\mathrm{An}_{72.9}\right)$, whereas groundmass plagioclase are relatively sodic $\left(\mathrm{An}_{39.2}-\mathrm{An}_{61.6}\right)$. Groundmass opaque minerals are characteristically found to be $\mathrm{Ti}^{-}$ magnetite/ilmenite/pyrophanite. Pyroxene thermometry reveals a temperature span of $850^{\circ}$ to $1280^{\circ} \mathrm{C}$ for the studied lavas while olivine-clinopyroxene thermometry yields a temperature range from $1040^{\circ}-$ $1160^{\circ} \mathrm{C}$. The variation of temperature for the lava flows is ascribed to their normal cooling history after eruption.
\end{abstract}

\section{Introduction}

The Deccan Volcanic Province (DVP) represents one of the largest continental Large Igneous
Provinces (LIPs) on the earth that records immense accumulations of laterally extensive flood basalt lava flows that erupted over a relatively short time span in an intraplate tectonic regime. The

Keywords. Eastern Deccan Volcanic Province; lava flows; primary volcanic structures; thermometry. 
significance of Deccan Trap Flood Basalt Province in the global scenario is attributed to its enormous volume and eruption duration that overlapped with the Cretaceous-Tertiary boundary ( 65-66 Ma) (Courtillot et al 1988; Duncan and Pyle 1988; Venkatesan et al 1993; Baksi 1994; Mahoney and Coffin 1997; Allegre et al 1999; Courtillot and Renne 2003; Sheth 2007; Ernst and Bell 2010; Melluso et al 2010; Sen and Chandrasekharam 2011). Pande (2002) surmised that an intense pulse of volcanism occurred at $66.9 \pm$ $0.21 \mathrm{Ma}$, preceeding the $K-T$ boundary (65.2 \pm Ma) event by $1.7 \mathrm{Ma}$. This pulse of volcanism induced pervasive lateral flows of Deccan lavas, both cumulatively and as individual flows with an approximate volume of $2 \times 10^{6} \mathrm{~km}^{3}$ (Self et al 1997). Deccan volcanism has covered an exposed area of about $\sim 1.5 \times 10^{6} \mathrm{~km}^{2}$ (Sen 2001) in the northwestern, western, central and southern parts of the Indian peninsula with rapid, widespread extrusion of lavas. Thus, voluminous, fissure-fed, outpourings of basaltic lavas and associated plumbing system of dykes, sills and layered intrusions represent spectacular manifestations of the earth's internal activity (Coffin and Eldholm 1994; Eldholm and Coffin 2000; Sheth et al 2009). It has been suggested that the primitive Deccan magmas of picritic compositions were generated from a large plume. However, recent studies reveal that the tholeiitic basalts, constituting the dominant magma type of Deccan Traps, are a product of melts derived from a combination of mantle plume, the subcontinental lithospheric mantle and eclogitic blocks embedded within the continental lithosphere (Sheth et al 2009; Sen and Chandrasekharam 2011).

The extensive lava flows from different parts of DVP emphasize the need to constrain the eruptive styles, flow morphology and emplacement and stratigraphic correlation on the basis of suitable parameters. Physical volcanological aspects manifested in terms of primary volcanic

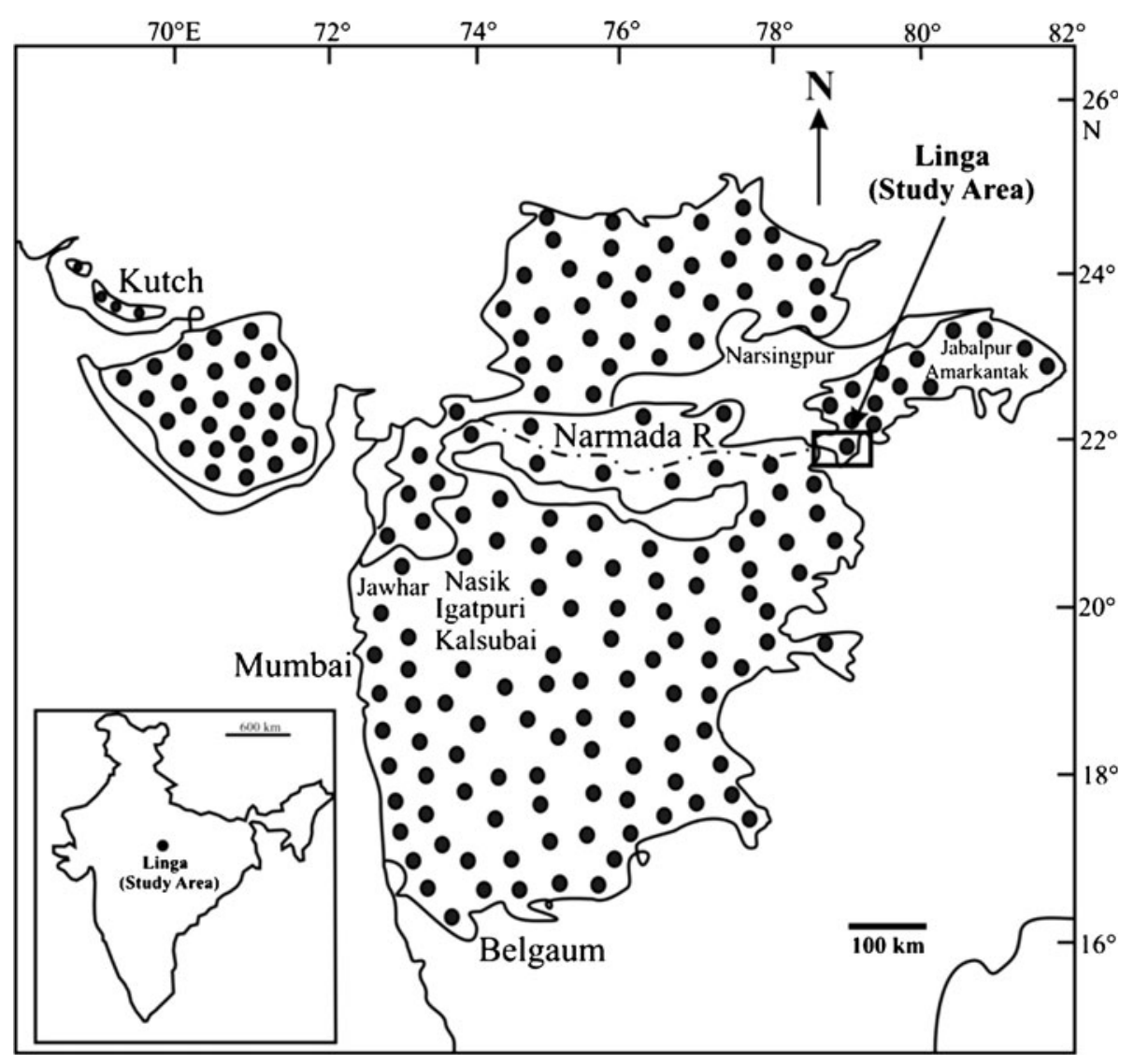

Figure 1. Map showing distribution of Deccan Traps (stippled) in India. It may be noted that (a) the areas including Jawhar, Nasik, Igatpuri, Kalsubai, etc., are referred to in the literature as Western Deccan and (b) the areas occupying eastern portion of Deccan outcrop adjacent to eastern side of Narmada river are generally referred to in the literature as Eastern Deccan. The proposed study area around Linga (marked by square) thus falls in Eastern Deccan segment. Inset map shows location of the study area in the map of India. 
structures that developed during the early stages of cooling and solidification of Deccan lavas provide significant criteria for the identification and characterization of lava flows (Anderson et al 1999). However, these features were not considered for systematic description and classification of Deccan lavas until De $(1972,1974)$ recognized the importance of volcanic structures and proposed a three-tier classification scheme consisting of five structural zones for the Deccan Traps. These structural zones are:
Upper Colonnade Zone (UCZ) grading into Upper Vesicular Zone (UVZ)

Entablature Zone (EZ)

Lower Colonnade Zone (LCZ) grading into Lower Vesicular Zone (LVZ)

In the western DVP, long-distance correlations of lavas and lava piles have been done using volcanological features, geochemistry and geochronology and the observations have been successfully used to understand the stratigraphic and structural

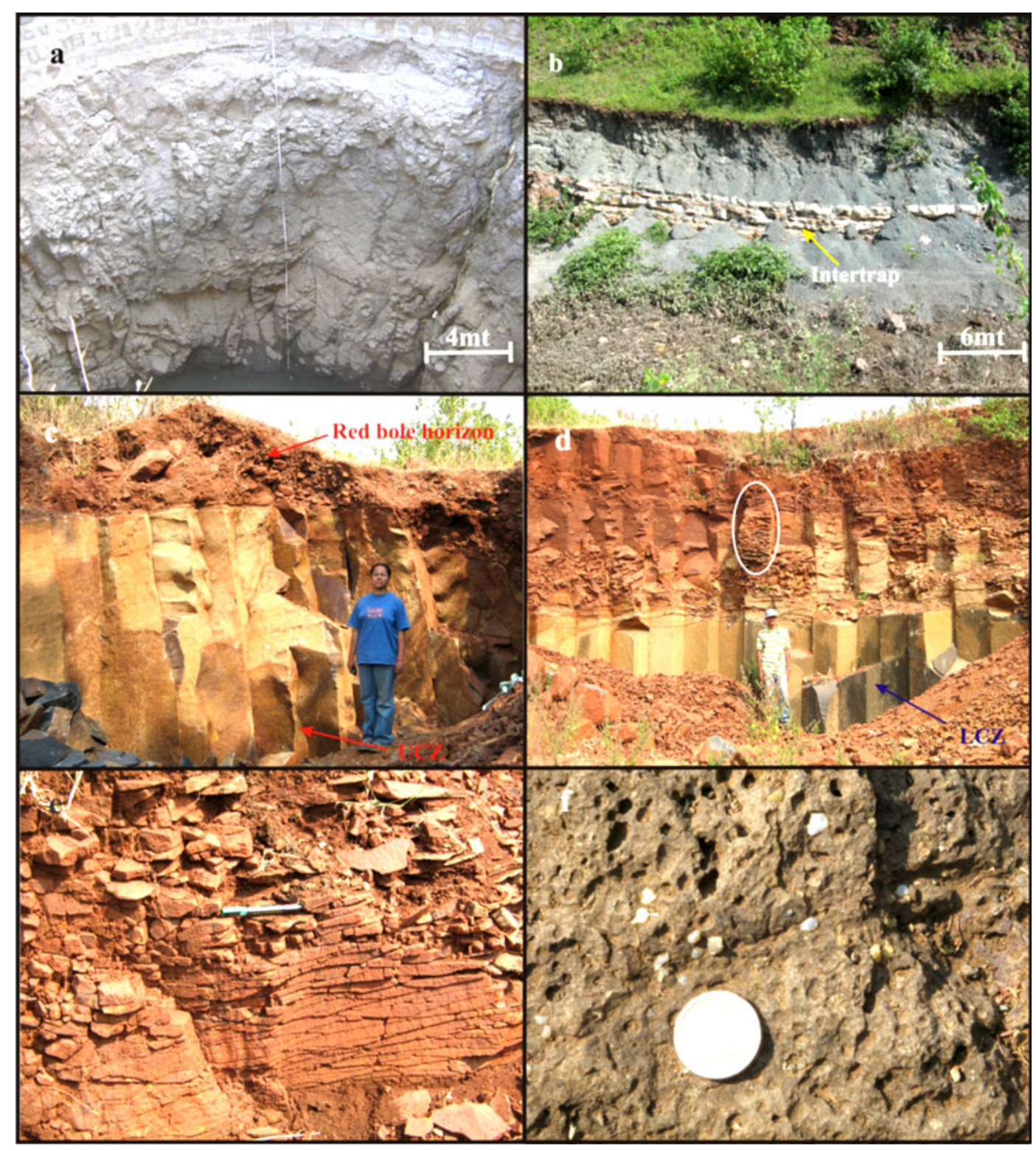

Figure 2. (a) Exposure of BG II in a well-section showing Upper Colonnade Zone (UCZ) grading into Upper Vesicular Zone (UVZ). (b) Field photograph showing occurrence of intertrap between SL II and SL III. (c) Upper Colonnade Zone (UCZ) with prominent development of columns. A thick Red Bole horizon is exposed at the top. (d) Lower Colonnade Zone (LCZ). The encircled portion shows that the columnar joint surface is segmented into step-like features known as chisel marks. (e) Entablature Zone (EZ) showing multidirectional hackly jointing. (f) Exposure of Lower Vesicular Zone (LVZ) showing vesicle filling by secondary minerals. 
make-up of these parts of Deccan (Mahoney et al 1982, 2000; Cox and Hawkesworth 1984; Devey and Lightfoot 1986; Subbarao and Hooper 1988; Keszthelyi and Self 1998). In this regard, it is worth mentioning that Cox and Hawkesworth (1985) and Beane et al (1986) made a significant contribution by presenting a 'geochemical stratigraphy' of the Deccan lavas from the Western Ghats. Morphological aspects of lava flows and quantitative studies on flow-emplacement have been documented from different parts of the western DVP and compared with those from other Continental Flood Basalt (CFB) provinces (Keszthelyi and Self 1998; Keszthelyi et al 1999; Duraiswami et al 2008). Emplacement and inflation of pahoehoe lava flows have been recorded from Deccan Traps and compared with that from Kilauea Volcano, Hawaii (Hon et al 1994; Sheth 2006). Compound pahoehoe flows including inflated sheets, hummocky flows and tumuli, from older stratigraphic formations and simple flows forming extensive sheets capped by vesicular, weathered crust or flow-top breccias in younger formations have been described from Pune and Sangamner areas of western DVP (Self et al 1998; Bondre et al 2000, 2004, 2006). Recent studies on lava flows in the Koyna-Satara region of western DVP (Sheth et al 2011) suggest sinking of flow-top breccias (into the molten interiors of the flows) which distorts isotherm-patterns ultimately causing radial columnar joint structures or rosettes. Studies on morphology and structure of flow-lobe tumuli and associated features have been carried out in the Deccan lavas from Pune and Dhule areas of western DVP (Duraiswami et al 2001, 2002). In comparison to these, eastern DVP (EDVP) has been less attended (Fermor and Fox 1916; Crookshank 1936; Alexander and Paul 1977). However, comprehensive work on chemical stratigraphy and flow correlation of Deccan lavas in a few sections in the north and south of Narmada have been worked out later by Yedekar et al (1996); Deshmukh et al (1996); De (1996). A comparison and correlation of flow sequences from northern parts of Deccan with that from Western Ghats have also been discussed (Nair et al 1996; Mahoney et al 2000). Pattanayak and Shrivastava (1996a, 1996b, 1999) established presence of 37 lava flows and eight chemical types from Mandla lobe on the basis of physical criteria, petrographic characters and major oxide compositions. Peng et al (1998), on the basis of $\mathrm{Nd}-\mathrm{Sr}-\mathrm{Pb}$ isotopes suggested presence of Mahabaleshwerlike lava flows in this area. Recently, occurrence of small-scale inflated pahoehoe lava flows has been reported from the Mandla lobe of the eastern DVP (Kashyap et al 2010). The three-tier classification scheme for Deccan lavas (De 1972, 1974) has also been used for erecting lava-stratigraphy from
Narsingpur-Harrai-Amarwara-Lakhnadon areas of EDVP (Sengupta and Ray 2007, 2011).

The present study area around Linga $\left(21^{\circ} 58^{\prime} \mathrm{N}\right.$ : $\left.78^{\circ} 56^{\prime} \mathrm{E}\right)$ in the Chhindwara district, Madhya Pradesh lies in the western margin of the Mandla lobe of the EDVP (figure 1). This area represents an important section of EDVP and reveals extensive lava flows with prominent development of primary volcanic structures which serve as an effective tool for the identification and characterization of lava flows in the area. In the present contribution, the physical volcanological aspects of the lava flows complemented by detailed petrography and mineral chemical parameters have been worked upon to track sequential variations among lava flows and elucidate the flow morphology.
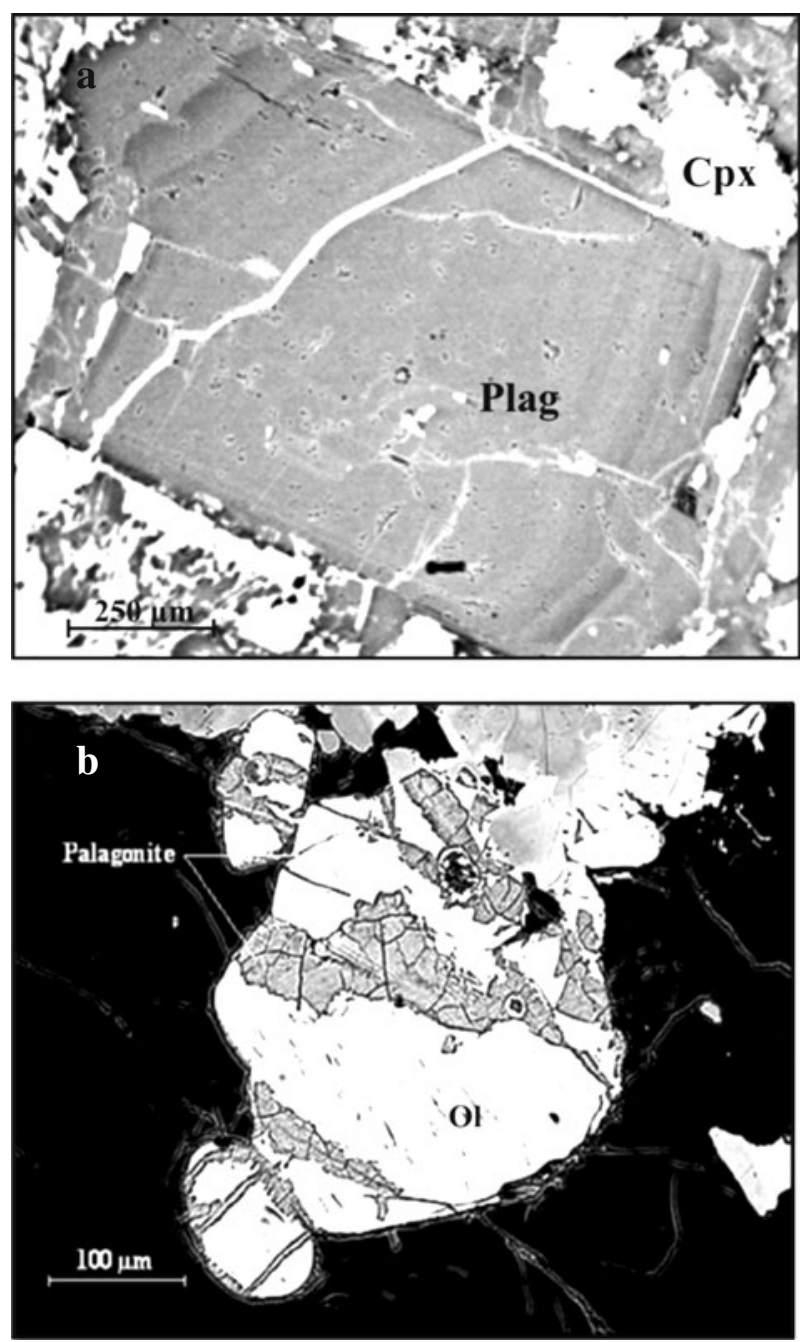

Figure 3. (a) Back-scattered image showing well-developed phenocryst of plagioclase in sample D 97 from LCZ (Lower Colonnade Zone) of SL III. (b) Back-scattered image showing olivine phenocryst partially altered to palagonite in sample D2 from EZ (Entablature Zone) of SL II. Explanation of abbreviations are same as in figure 2 . 


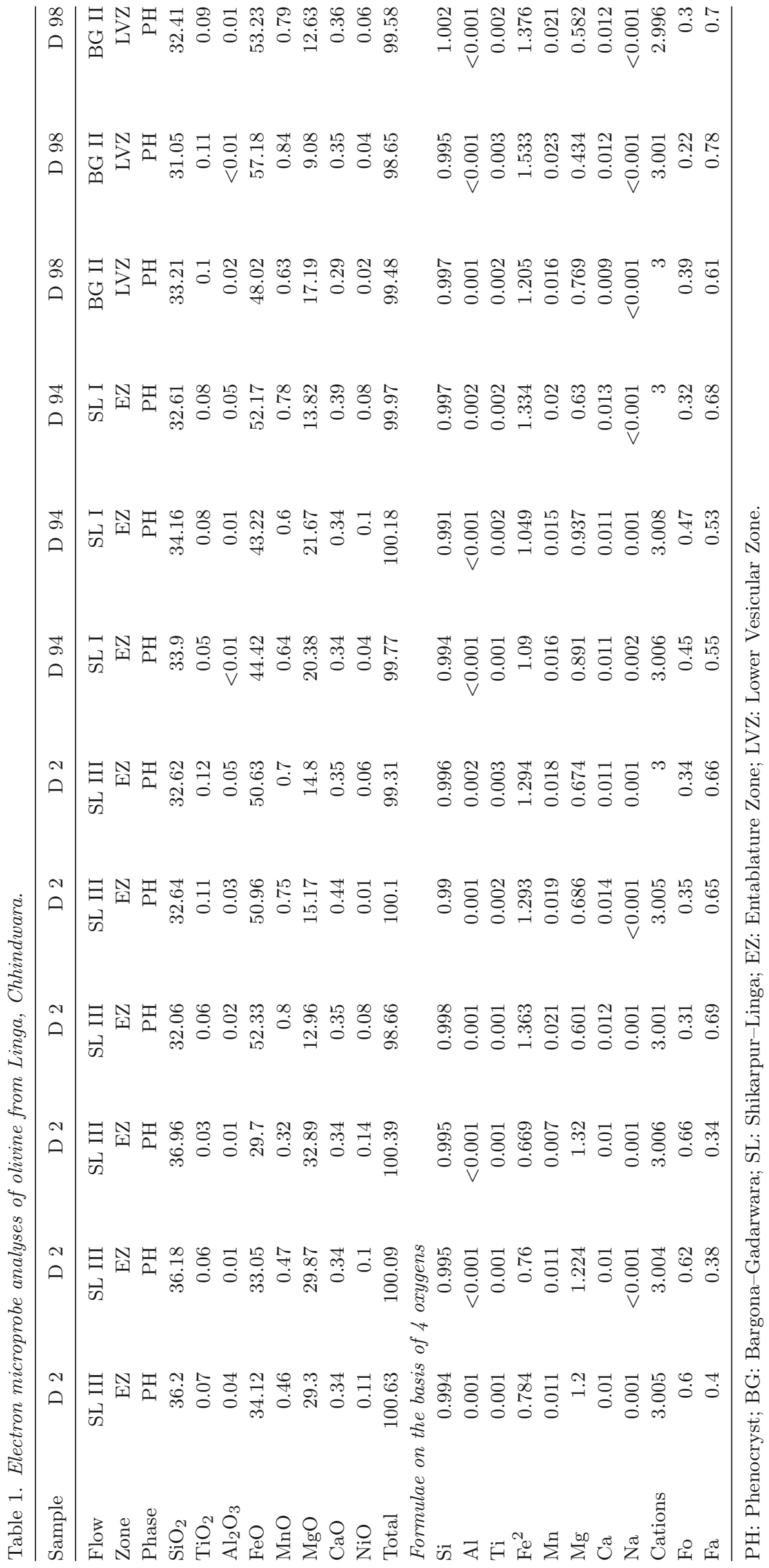




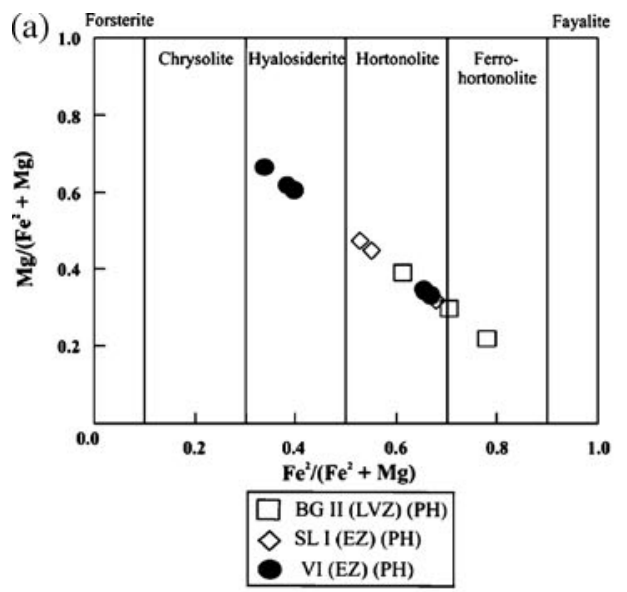

(c)

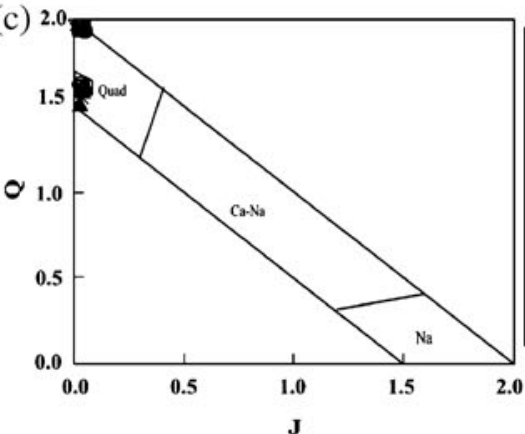

(e)

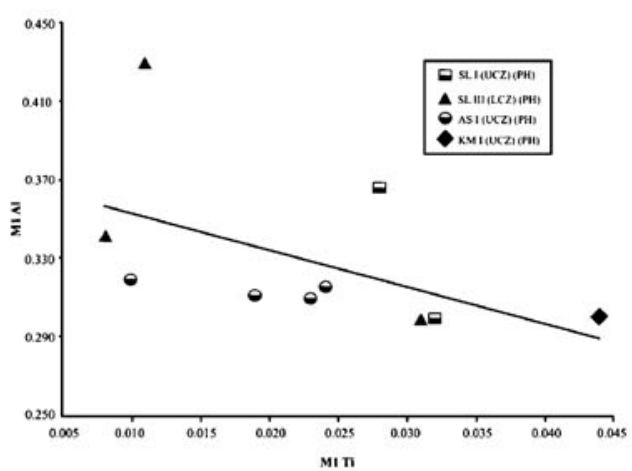

(b)

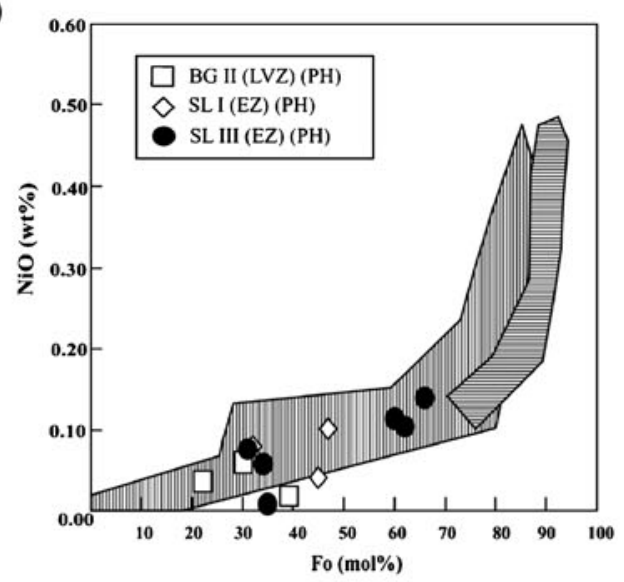

(d)
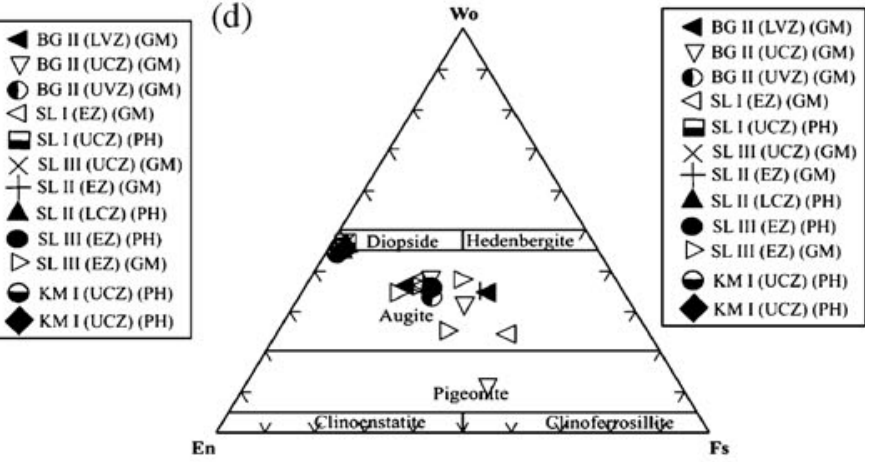

(f)

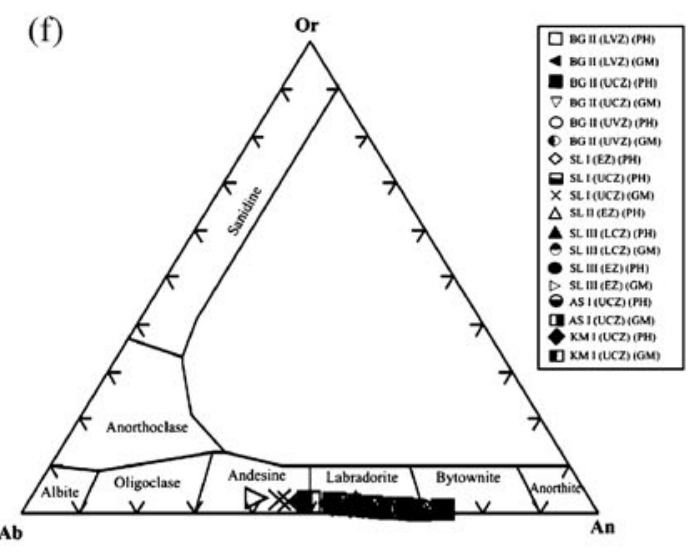

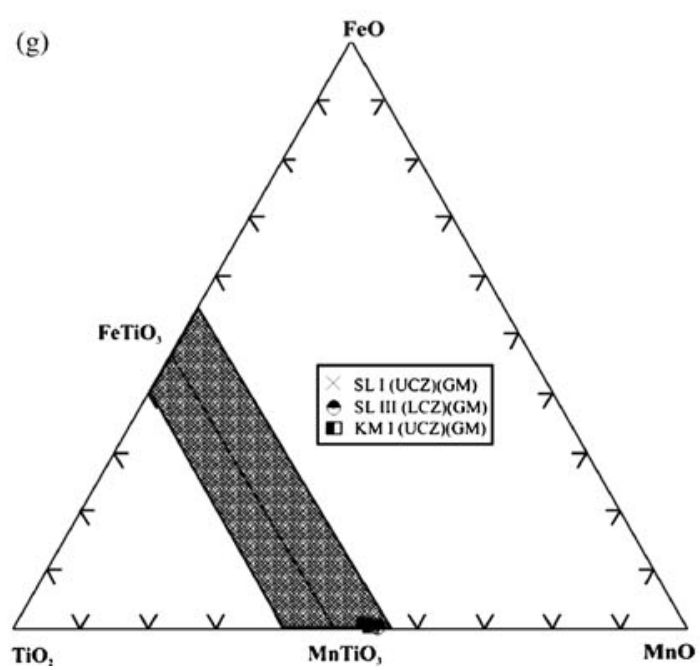




\section{Identification and characterization of lava flows}

Different lava flows have been identified and characterized in the field in the presently investigated area at and around Linga. These basaltic lava flows are spatially distributed in four different sectors viz., (i) Bargona-Gadarwara (BG) sector (ii) Shikarpur-Linga (SL) sector (iii) ArjunvariSurvir Hill (AS) sector and (iv) KukrachimanMorand Hill (KM) sector. Each and every flow is primarily identified on the basis of systematic arrangement of distinct volcanological features such as columnar joints and vesicles. Presence of intertrappean beds, red bole and green bole horizons provides suitable parameters to distinguish individual flows from one another. In the BargonaGadarwara (BG) sector, three lava flows have been identified and designated as Flows BG I, BG II and BG III. Flow BG I is exposed in a well-section near Gadarwara village (figure 2a) and an intertrap of $0.61 \mathrm{~m}$ separates BG I from BG II. The SL sector reveals three well-defined lava flows named as Flows SL I, SL II and SL III. Flow SL I is exposed in a well-section. An intertrappean horizon occurs between the Flows SL II and SL III (figure 2b). A single lava flow (AS I) is exposed in the AS sector and similarly the KM sector also reveals a single flow (KM I). A three-tier classification scheme of primary volcanic structures (De 1972, 1974, 1996) has been adopted here for characterization and classification of individual lava flows in the study area. Primary volcanic structures such as columnar joints, multi-directional hackly joints and vesicles have been used to classify each flow into three welldefined structural zones. This includes the LCZ overlain by the EZ and the UCZ. The LCZ of a single lava flow in the study area is characterized by well-developed columns with prominent columnar jointing in the lower part of the flow including a vesicular lower contact. The upper part of the flow is characterized by polygonal columns of solidified lavas forming the UCZ which merges with the upper vesicular part (figure $2 \mathrm{c}$ and $\mathrm{d}$ ). In between the LCZ and UCZ, there is a central zone, called the EZ, which is characterized by multi-directional fracture patterns and exhibits distinct hackly jointing (figure 2e). In Flow AS I, polygonal traces of columnar joints have been identified in plan. The upper part of UCZ and lower part of LCZ of the studied flows are typified by closely spaced numerous vesicles and these zones of the lava flows are known as UVZ and LVZ, respectively. The diameter of vesicles in the LVZ ranges from $0.1-1 \mathrm{~cm}$, while the vesicles in UVZ are remarkably larger with diameter ranging from 1.5-4 cm. Amygdules with secondary infillings are commonly developed in LVZ and UVZ of the flows (figure 2f). The nature and size of vesicles help to distinguish different flows in some cases. The LVZ and UVZ of Flows BG II, SL III, AS I and KM I are characterized by dark green and red soils intermixed with weathered, sub-rounded basaltic boulders. These represent the green bole and red bole horizons (figure $2 \mathrm{c}$ ), which have developed due to intense weathering of highly vesicular basalts of LVZ and UVZ. The top surface of the lava flows, especially the vast expanse of flows along the nullah sections, reveal bulbous, lobe-like appearance with lateral toeing of lava and resemble the pahoehoe lava characters of Deccan Traps.

\section{Petrography}

Petrographic studies of the lava flows represent inequigranular phenocrystal basalt characterized by development of phenocrystal phases such as plagioclase, clinopyroxene, olivine. Groundmass composition is generally marked by plagioclase, granular pyroxene, opaque minerals and glass.

Plagioclase phenocrysts are mostly lath-shaped (figure 3a) with occasional presence of tabular grains. Clinopyroxene phenocrysts are mostly prismatic and occur in two different varieties. One type is found as medium-sized, subhedral grains, while the other type occurs as microphenocrysts, which

Figure 4. (a) Plot of analysed olivine phenocrysts of investigated Deccan basalt samples in the olivine classificatory diagram (modified after Deer et al 1979). (b) Plot of investigated olivine phenocrysts in NiO (wt\%) vs. Fo (mol \%) diagram (Fleet et al 1977). The field with horizontal striations indicates olivine compositions for upper mantle while field with vertical striations indicates olivine compositions of basalt, diabase and layered intrusions. (c) Plot of investigated pyroxene compositions of Deccan basalt samples in Q-J diagram (Morimoto 1989) [where Q $=(\mathrm{Ca}+\mathrm{Mg}+\mathrm{Fe}$ ) a.p.f.u. and J = 2 Na a.p.f.u.]. (d) Plot of investigated pyroxene compositions of Deccan basalt samples in Wollastonite (Wo)-Enstatite(En)-Ferrosilite(Fs) diagram (Morimoto 1989). (e) Plot of analysed pyroxene phenocrysts from investigated Deccan basalts in Al (M1) vs. Ti (M1) diagram. (f) Projection of investigated plagioclase compositions in Orthoclase(Or)-Albite(Ab)-Anorthite(An) triangular diagram; PH: Phenocryst and GM: Groundmass. (g) Plot of investigated pyrophanite compositions in $\mathrm{MnO}^{-\mathrm{TiO}}{ }_{2}-\mathrm{FeO}$ diagram. Shaded region represents pyrophanite compositions from several other areas of the world (Craig et al 1985). Explanation of abbreviations are same as in figure 2. 


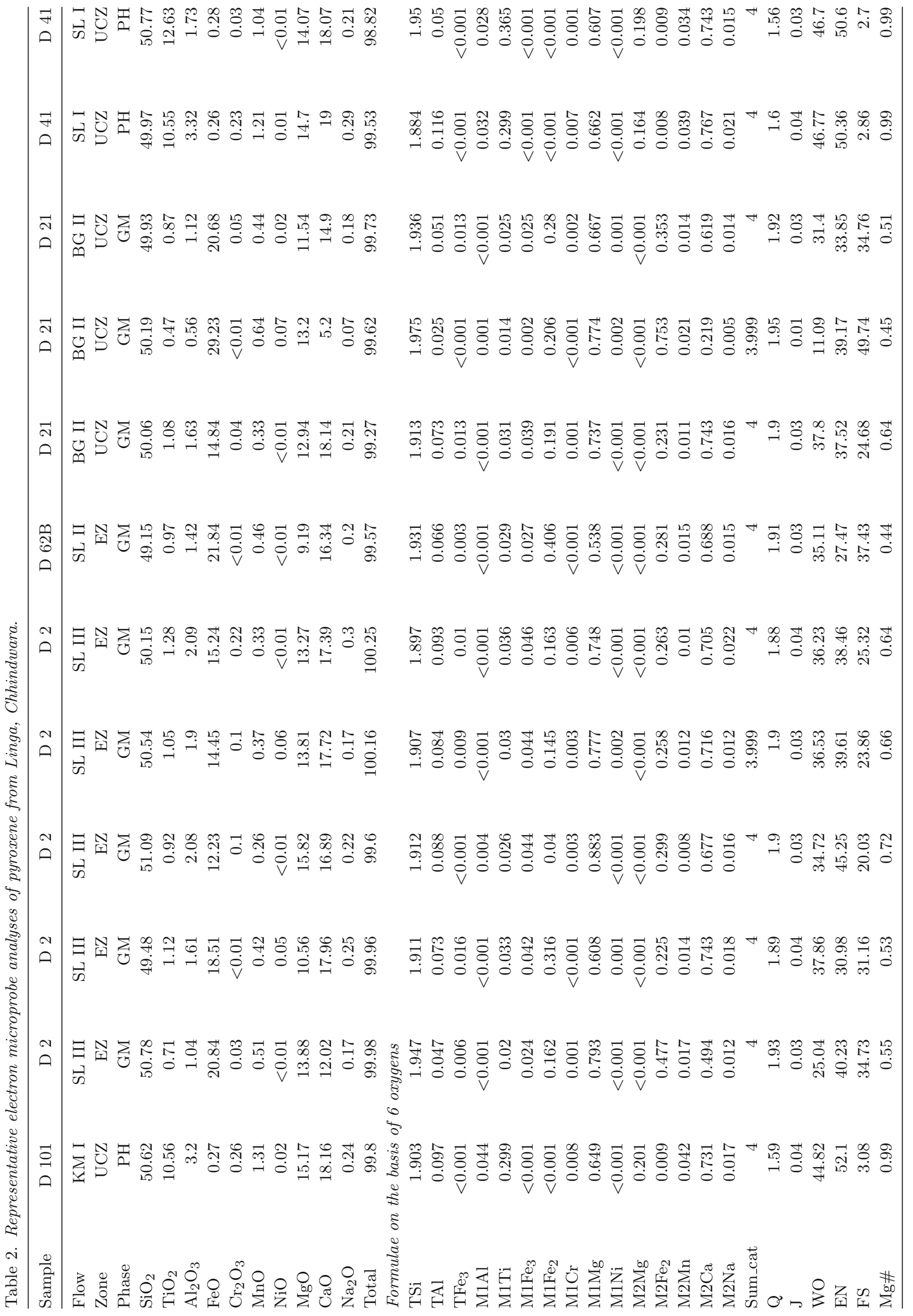




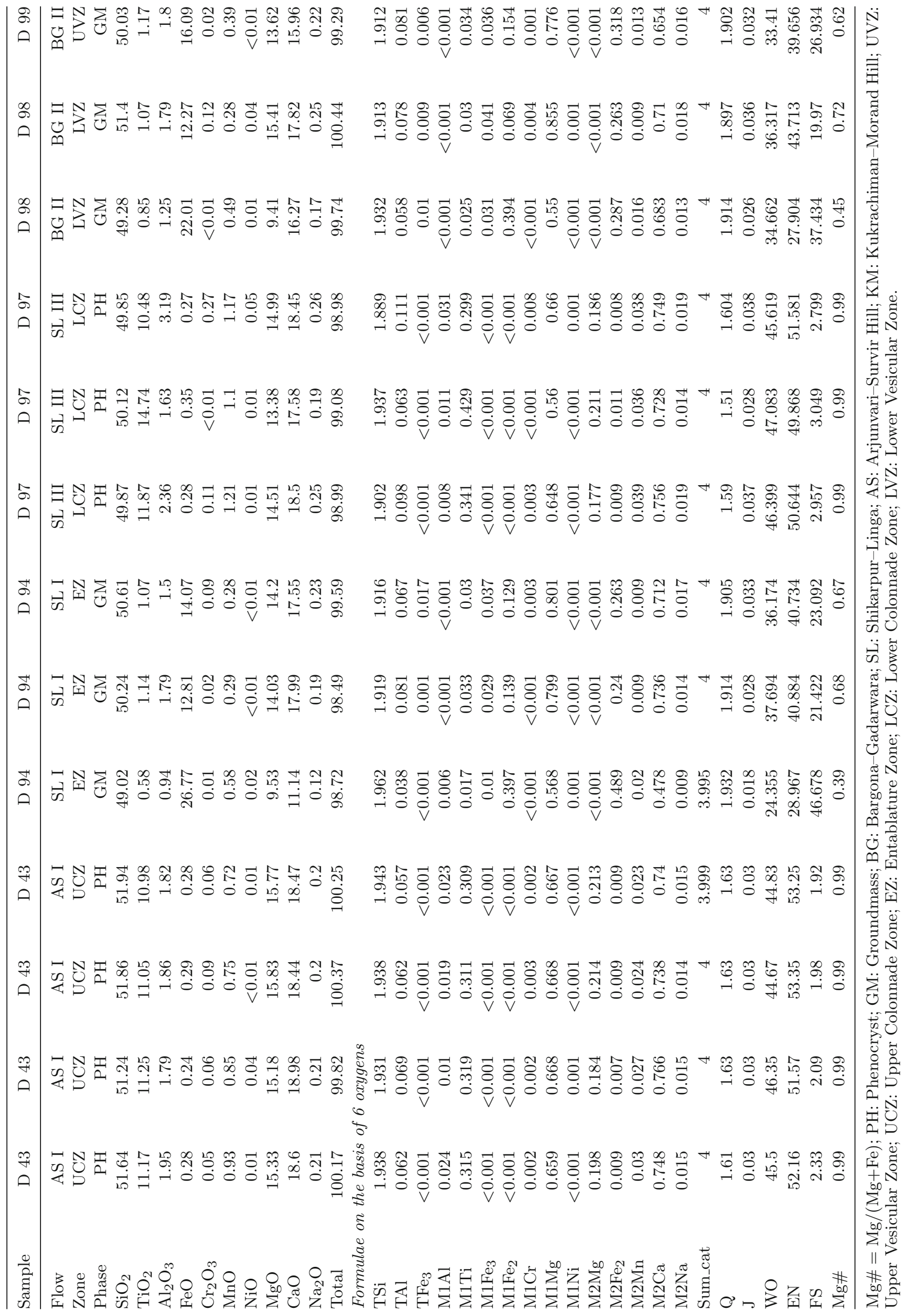




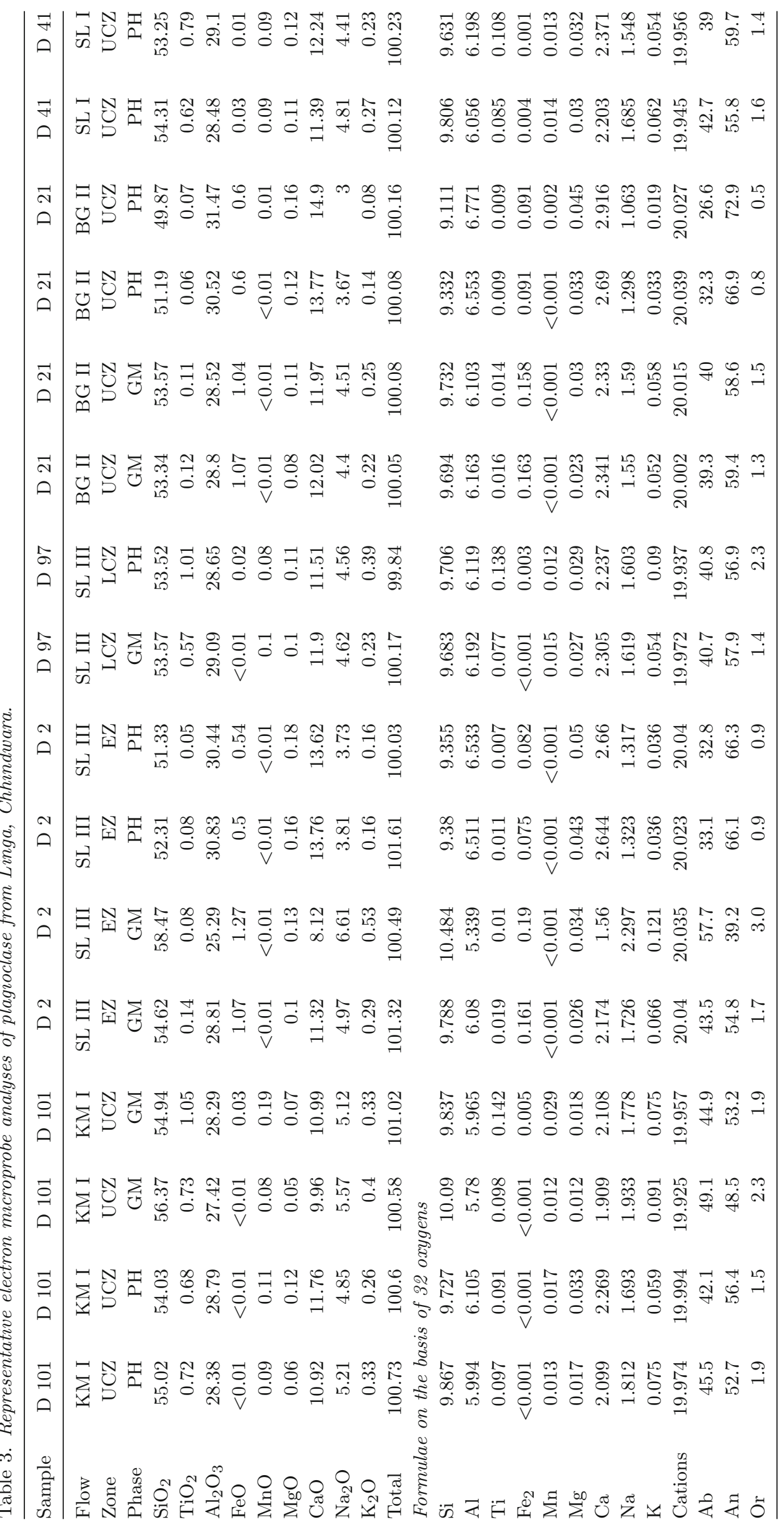




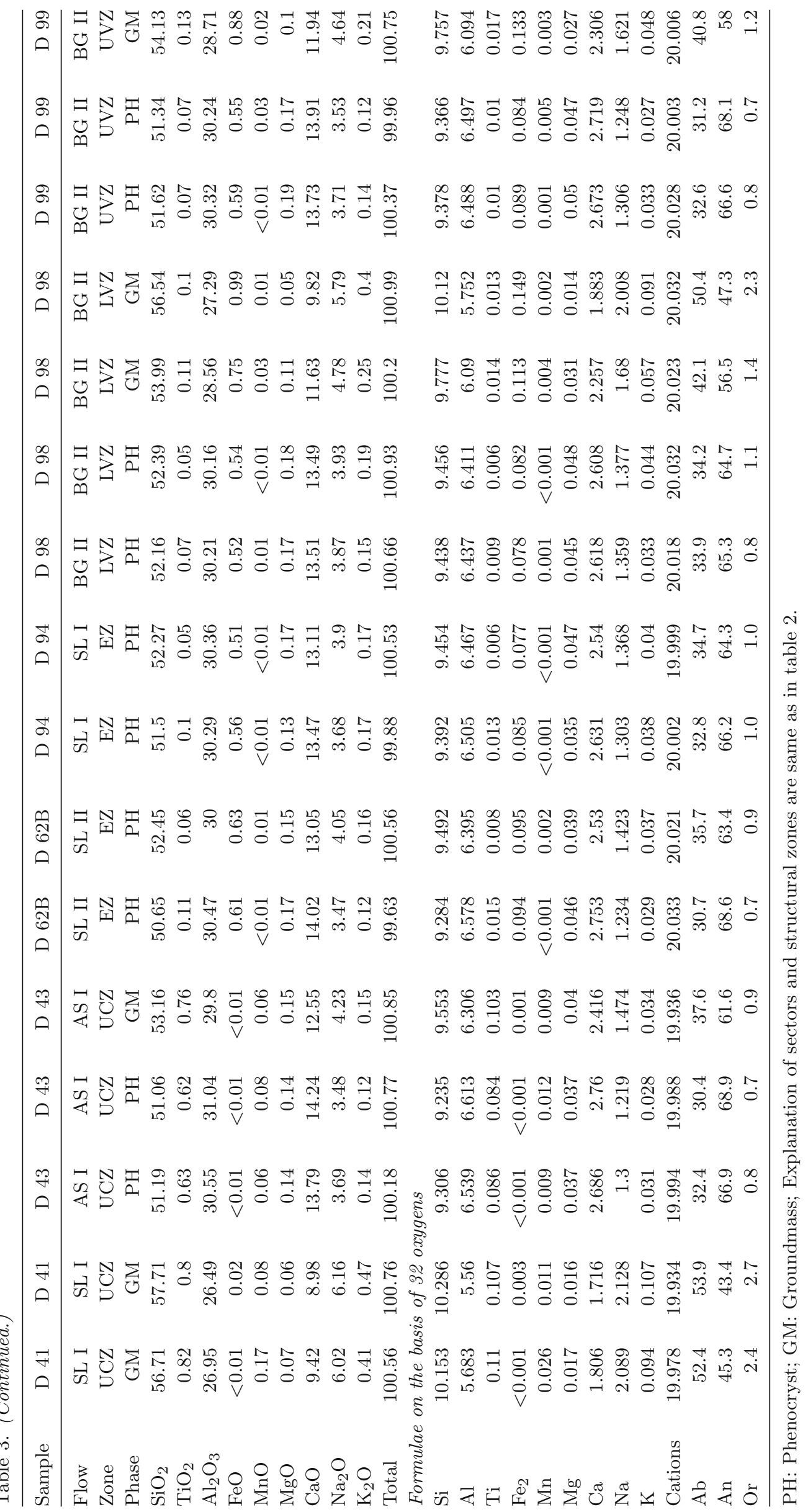


cluster together to form tecoblast. In glass-rich samples from the EZ basalts, clinopyroxene grains show anomalous wavy extinction, giving rise to an hour-glass structure. Olivine phenocrysts are completely or partially altered to palagonite (figure 3b) and iddingsite, but the relict olivine grains can be recognized by their common euhedral morphology, high relief and high birefringence. Two varieties of palagonite, viz., chlororophaeite and delessite (occuring as spherules or irregular patches) have been recognized from the investigated flows. A similar report on the occurrence of altered glass has earlier been described from this locality (Fermor and Fox 1916; West 1958). Chlorophaeite shows light-yellow to deep-yellow colour and has formed as an alteration product of olivine and glass. Delessite is green in colour. Devitrification is also observed in some places. The overall textural pattern of investigated lava flows is defined by ophiticsubophitic and intersertal-intergranular textures. Distinct development of clustered plagioclase phenocryts represents glomeroporphyritic texture.

\section{Mineral chemistry}

Electron microprobe analyses of constituent mineral phases of investigated lava flows were performed at the Department of Lithospheric Research, University of Vienna, using a four spectrometer CAMECA SX100 microprobe. Counts were obtained simultaneously using a $15 \mathrm{keV}$ accelerating voltage, a 1-2 $\mu \mathrm{m}$ beam diameter, and a beam current of $20 \mathrm{nA}$. Natural and synthetic standards were used for calibrations and the PAP (Pouchou and Pichoir) correction (Pouchou and Pichoir 1991) was applied to the data.

\subsection{Olivine}

Olivine represents a significant phenocrystal phase in the lava flows. Modal proportion of olivine phenocrysts exhibits a gradual decreasing trend from LVZ to UVZ of corresponding flows (Flows SL I, SL II and SL III) suggesting their prominent concentration in the lower portion of the lava flows than that in the upper portion (Cox and Mitchell 1988). This feature has been recorded from Deccan lavas in the Western Ghats and has been attributed to settling of olivine in a largely liquid lava flow after the flow was emplaced, happening several times (Beane and Hooper 1988). Few olivine phenocrysts are also present in the UCZ for Flow BG II. Some of the olivine phenocrysts in the lava flows are partially to completely iddingsitized, reflecting the effects of low-temperature alteration 
(Damasceno et al 2002). Electron microprobe analyses of olivine phenocrysts from Flows BG II, SL I and SL III are presented in table 1. The Fo (forsterite) content of olivines ranges from $\mathrm{Fo}_{20}{ }^{-}$ $\mathrm{Fo}_{66}$ indicating a wide spectrum of compositional variation. The compositional spectrum of phenocrystal olivines corroborates a changing crystallization condition in the prevailing magmatic environment. The low $\mathrm{MgO}$ content and relatively Fe-rich nature of the analysed olivine phenocrysts indicate a much-evolved composition of the magma. The data plots corresponding to investigated olivine compositions exhibit a wide scatter occupying the fields of hyalosiderite, hortonolite and ferrohortonolite (figure 4a) (modified after Deer et al 1979). The compositions of olivine phenocrysts from UCZ of Flow BG II and EZ of Flow SL I range from hortonolite to ferrohortonolite, while that from EZ of Flow SL III range from hyalosiderite to ferrohortonolite. $\mathrm{NiO}$ in wt\% of analysed olivine phenocrysts has been plotted against respective Fo (mol \%) content in biaxial diagram proposed by Fleet et al (1977), where the data plots distinctly correspond to the field of olivine compositions of basalts (figure 4b).

\subsection{Pyroxene}

Mineral chemistry (table 2) obtained from 26 pyroxene analyses represents both phenocrystal and groundmass compositions from respective zones of Flows BG II, SL I, SL II, SL III, AS I and KM I. The analysed pyroxene compositions have been considered in order to classify them in a systematic manner on the basis of ' $Q$ ' and ' $\mathrm{J}$ ' relations (Morimoto et al 1988). As per 'Q' and 'J' relations (where $\mathrm{Q}=\mathrm{Ca}+\mathrm{Mg}+\mathrm{Fe}$ and $\mathrm{J}=2 \mathrm{Na}$ ) (expressed in terms of a.p.f.u), the pyroxenes are designated as 'QUAD' pyroxenes (Morimoto 1989) (figure 4c). The pyroxene phenocryst data plots cluster in the fields of 'diopside' and the groundmass pyroxenes mostly correspond to 'augite' with a minor spill to 'pigeonite' in the Wo-En-Fs triangular diagram (Morimoto 1989) (figure 4d). The Mg\# of groundmass clinopyroxene varies from 0.34 to 0.72 , while phenocrystal clinopyroxenes are characterized by $\mathrm{Mg} \#$ 0.99. Pyroxene phenocrysts from UCZ of Flows SL I, AS I, KM I and those from LCZ of Flow SL III are characterized by a prominent enrichment in $\mathrm{TiO}_{2}$ (ranging from 10.5-14.7 wt\%). The high titanium content of pyroxene phenocrysts is a result of $\mathrm{Ti} \leftrightarrow \mathrm{Al}^{\mathrm{VI}}$ replacement as depicted in figure $4(\mathrm{e})$. The strikingly large titanium content of the phenocrystal pyroxenes from the basaltic lava flows at and around Linga exceeds that of titanaugite reported from alkali olivine basalts of Tahiti $\left(\mathrm{TiO}_{2}\right.$ ranging from $4.24-8.73 \mathrm{wt} \%$ ) and other previously reported Ti-rich augites (Dixon and Kennedy 1933; Tracy and Robinson 1977).

\subsection{Plagioclase}

When the analysed plagioclase compositions (table 3) are projected into $\mathrm{Or}-\mathrm{Ab}-\mathrm{An}$ triangular diagram (figure 4f), the data-plots depict a compositional spectrum ranging from andesine to bytownite varieties. The anorthite component of plagioclase of the investigated basalts varies from $\mathrm{An}_{39.2}$ to $\mathrm{An}_{72.9}$. The phenocrystal plagioclase are calcic, while a relatively sodic composition is noted for the groundmass.

\subsection{Glass}

Glass is present only in groundmass of the investigated lava flows. Analysed glass compositions have been furnished in table 4 .

\subsection{Opaque minerals}

Opaque minerals mostly occur as groundmass in the investigated lava flows. The analysed compositions of opaque (table 5) from UVZ of Flow BG II and EZ of Flow SL I correspond to Timagnetite, while the opaque phases from UCZ of Flows BG II and KM I belong to ilmenite species. UCZ of Flow SL I, Flow KM I and LCZ of Flow SL III are characterized by the presence of pyrophanite $\left(\mathrm{MnTiO}_{3}\right)$, the manganese analogue of ilmenite. Electron microprobe analyses of pyrophanite (table 6) from UCZ of Flows SL I, KM I and LCZ of Flow SL III have been projected in the $\mathrm{MnO}-\mathrm{TiO}_{2}-\mathrm{FeO}$ diagram (Craig et al 1985) (figure $4 \mathrm{~g}$ ), where most of the plots cluster close to the field of pyrophanite compositions from several other areas of the world.

\section{Geothermometry}

\subsection{Pyroxene thermometry}

An effective method of determining temperature with the help of pyroxene compositions was proposed by Lindsley (1983). Recalculation of pyroxene compositions in terms of several endmember molecules and subsequent plotting of those recalculated molecules in terms of experimentally determined pyroxene thermal-contours yield temperatures varying between $850^{\circ}$ and $1280^{\circ} \mathrm{C}$ for the corresponding zones of the investigated lava flows (figure 5). Temperatures calculated for the $\mathrm{UCZ}$ of Flow BG II range from $850^{\circ} \mathrm{C}$ and $1280^{\circ} \mathrm{C}$ and that for the LVZ and UVZ of BG II have been 
Table 5. Electron microprobe analyses of Ti-magnetite and ilmenite from Linga, Chhindwara.

\begin{tabular}{|c|c|c|c|c|}
\hline Sample & D 94 & D 99 & D 21 & D 98 \\
\hline Flow & SL I & BG II & BG II & BG II \\
\hline Zone & EZ & UVZ & UCZ & UCZ \\
\hline Phase & GM & GM & GM & GM \\
\hline $\mathrm{SiO}_{2}$ & 0.07 & 0.1 & 0.01 & 0.04 \\
\hline $\mathrm{TiO}_{2}$ & 24.78 & 26.58 & 51.49 & 51.65 \\
\hline $\mathrm{Al}_{2} \mathrm{O}_{3}$ & 1.94 & 2.16 & 0.1 & 0.03 \\
\hline $\mathrm{FeO}$ & 67.32 & 63.16 & 45.75 & 45.14 \\
\hline $\mathrm{Cr}_{2} \mathrm{O}_{3}$ & 0.13 & 0.11 & 0.03 & 0.07 \\
\hline $\mathrm{MnO}$ & 0.47 & 0.42 & 0.47 & 0.52 \\
\hline $\mathrm{MgO}$ & 1.18 & 1.87 & 1.44 & 1.34 \\
\hline $\mathrm{CaO}$ & 0.03 & 0.04 & 0.04 & 0.14 \\
\hline Total & 95.94 & 94.46 & 99.33 & 98.97 \\
\hline \multicolumn{5}{|c|}{ Formulae on the basis of 4 oxygens for Ti-magnetite and 3 oxygens for Ilmenite } \\
\hline $\mathrm{Si}$ & 0.003 & 0.004 & $<0.001$ & 0.001 \\
\hline $\mathrm{Al}$ & 0.092 & 0.102 & 0.003 & 0.001 \\
\hline $\mathrm{Ti}$ & 0.749 & 0.799 & 0.983 & 0.988 \\
\hline $\mathrm{Fe}^{2}$ & 2.263 & 2.109 & 0.971 & 0.959 \\
\hline $\mathrm{Cr}$ & 0.004 & 0.003 & 0.001 & 0.002 \\
\hline Mn & 0.016 & 0.014 & 0.01 & 0.011 \\
\hline $\mathrm{Mg}$ & 0.07 & 0.111 & 0.054 & 0.05 \\
\hline $\mathrm{Ca}$ & 0.001 & 0.002 & 0.001 & 0.004 \\
\hline Species & Ti-magnetite & Ti-magnetite & Ilmenite & Ilmenite \\
\hline
\end{tabular}

GM: Groundmass; explanation of sectors and structural zones are same as in table 2.

Table 6. Electron microprobe analyses of pyrophanite from Linga, Chhindwara.

\begin{tabular}{|c|c|c|c|c|c|c|c|}
\hline Sample & D 101 & D 101 & D 101 & D 41 & D 97 & D 97 & D 97 \\
\hline Flow & KM I & KM I & KM I & SL I & SL III & SL III & SL III \\
\hline Zone & $\mathrm{UCZ}$ & $\mathrm{UCZ}$ & $\mathrm{UCZ}$ & $\mathrm{UCZ}$ & LCZ & LCZ & LCZ \\
\hline Phase & GM & GM & GM & GM & GM & GM & GM \\
\hline $\mathrm{SiO}_{2}$ & 0.03 & 0.08 & 0.03 & 0.01 & 0.04 & 0.02 & 0.04 \\
\hline $\mathrm{TiO}_{2}$ & 44.96 & 46.24 & 44.96 & 46.79 & 44.32 & 44.64 & 44.32 \\
\hline $\mathrm{Al}_{2} \mathrm{O}_{3}$ & 0.05 & 0.03 & 0.05 & 0.19 & 0.03 & 0.04 & 0.03 \\
\hline $\mathrm{FeO}$ & 0.54 & 0.56 & 0.54 & 0.48 & 0.46 & 0.52 & 0.46 \\
\hline $\mathrm{MnO}$ & 51.98 & 50.85 & 51.98 & 50.44 & 52.19 & 52.65 & 52.19 \\
\hline $\mathrm{MgO}$ & 1.31 & 0.77 & 1.31 & 0.69 & 1.11 & 1.05 & 1.11 \\
\hline $\mathrm{CaO}$ & 0.06 & 0.03 & 0.06 & 0.01 & 0.1 & 0.04 & 0.1 \\
\hline Total & 98.93 & 98.63 & 98.93 & 98.63 & 98.27 & 99 & 98.27 \\
\hline \multicolumn{8}{|c|}{ Formulae on the basis of 3 oxygens } \\
\hline $\mathrm{Si}$ & 0.001 & 0.002 & 0.001 & $<0.001$ & 0.001 & 0.001 & 0.001 \\
\hline $\mathrm{Al}$ & 0.002 & 0.001 & 0.002 & 0.006 & 0.001 & 0.001 & 0.001 \\
\hline $\mathrm{Ti}$ & 0.888 & 0.911 & 0.888 & 0.919 & 0.884 & 0.884 & 0.884 \\
\hline $\mathrm{Fe}^{2}$ & 0.012 & 0.012 & 0.012 & 0.011 & 0.01 & 0.012 & 0.01 \\
\hline Mn & 1.156 & 1.128 & 1.156 & 1.115 & 1.172 & 1.174 & 1.172 \\
\hline $\mathrm{Mg}$ & 0.051 & 0.03 & 0.051 & 0.027 & 0.044 & 0.041 & 0.044 \\
\hline $\mathrm{Ca}$ & 0.005 & 0.003 & 0.005 & 0.001 & 0.008 & 0.003 & 0.008 \\
\hline
\end{tabular}

GM: Groundmass; explanation of sectors and structural zones are same as in table 2.

deduced to be $1150^{\circ}$ and $1250^{\circ} \mathrm{C}$, respectively. The equilibration temperature of EZ of Flows SL I, SL II and SL III ranges from $1080^{\circ}$ to $1280^{\circ} \mathrm{C}$, while that from UCZ of SL I and LCZ of SL III is around $1280^{\circ} \mathrm{C}$. The UCZs of Flows AS I and KM I record a temperature around $1280^{\circ} \mathrm{C}$. 


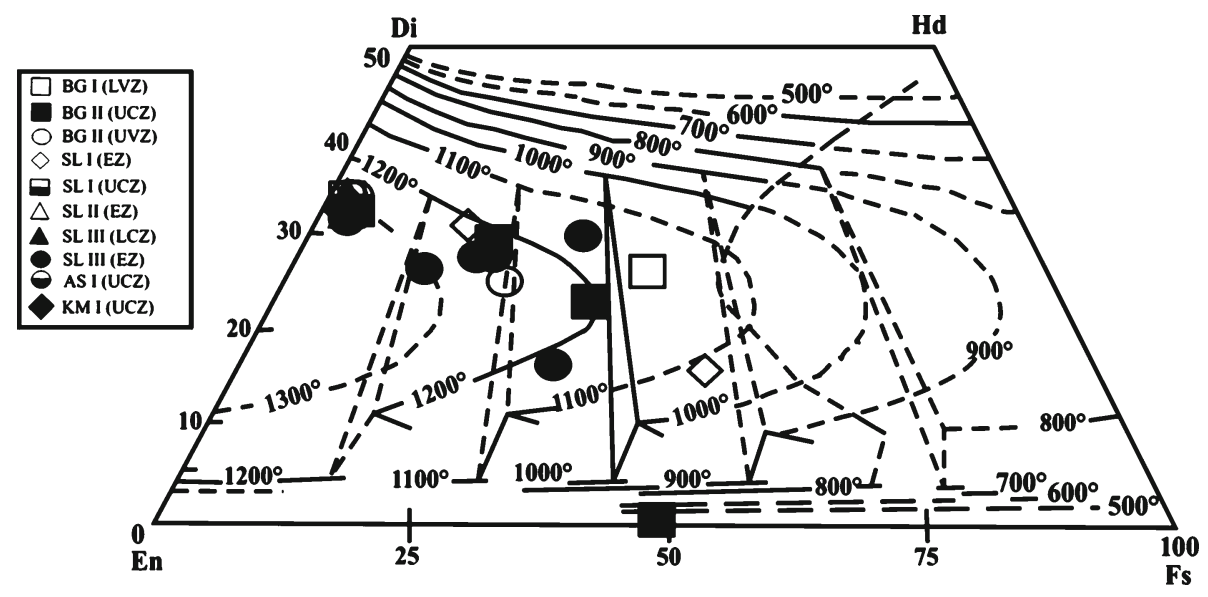

Figure 5. Projection of recalculated pyroxene compositions in Diopside(Di)-Hedenbergite(Hd)-Enstatite(En)Ferrosilite(Fs) diagram (Lindsley 1983) for thermometric calculations in ${ }^{\circ} \mathrm{C}$. For explanation of abbreviations, see figure 2 .

\subsection{Olivine-clinopyroxene thermometry}

On the basis of an olivine-augite $\mathrm{Mg}-\mathrm{Fe}$ exchange thermometer proposed by Loucks (1996), analyzed compositions of coexisting olivine and augite from Flows BG II, SL I and SL III have been considered for thermometric calculations. Geothermometric estimations evaluated on the basis of coexisting olivine-augite compositions yield temperatures ranging from $1040^{\circ}$ to $1160^{\circ} \mathrm{C}$. Flow BG II records a temperature of about $1055^{\circ} \mathrm{C}$, while temperatures deduced for Flow SL I range from $1040^{\circ}$ to $1085^{\circ} \mathrm{C}$ and that for Flow SL III vary from $1100^{\circ}$ to $1160^{\circ} \mathrm{C}$.

\section{Summary and discussion}

- The investigated basaltic lava flows at and around Linga, Eastern Deccan Volcanic Province have been identified by systematic arrangement of three-tier structural zones defined by colonnades, entablature and vesicles.

- Individual flows are marked by noting strikingly different fracture patterns existing in the colonnade zones and those in entablature zones.

- The LCZ and UCZ in general mark welldeveloped or moderately-developed six-sided columns while in EZ, multi-directional joint patterns (Peck and Minakami 1968; De 1996) and strong fragmental characters are evident.

- Field investigations in the study area reveal that the joint surfaces of the columns of LCZ of Flow SL II (figure 2d) are segmented into strips or step-like features which are commonly referred to as chisel marks (Philpotts and Ague 2009, p. 57). These are formed by individual fracture events that occur successively as the column propagates during the cooling of a flow.
- Petrographic studies indicate that the investigated lava flows are inequigranular phyric basalts with development of phenocrystal phases such as plagioclase, clinopyroxene and olivine. Groundmass is marked by plagioclase, granular pyroxene, opaque minerals and glass. The relative proportions of mineral phases in different lava flows (as well as in different zones of an individual lava flow) are variable and related to the cooling history.

- Electron microprobe analyses of phenocrystal olivine indicate a wide compositional spectrum, with $\mathrm{Fo}$ contents ranging from $\mathrm{Fo}_{22}-\mathrm{Fo}_{66}$. The olivine phenocrysts of presently investigated basaltic lavas show higher $\mathrm{CaO}$ content $(>0.25$ wt\%) than those of mantle peridotites where $\mathrm{CaO}$ content in olivine is commonly less than 0.1 wt\% (Simkin and Smith 1970). This higher $\mathrm{CaO}$ content shows that the olivine phenocrysts are not xenocrysts from mantle peridotite, but are products of crystallization from a mantlederived magma (Furuyama et al 2001). The low $\mathrm{NiO}$ content of olivine phenocrysts suggests a differentiated nature of the crystallizing magma. Composition of olivine phenocrysts from EZ of the lava flows falls in the range $\mathrm{FO}_{31}-\mathrm{Fo}_{66}$ while that from $\mathrm{LVZ}$ shows a range of $\mathrm{Fo}_{22}-\mathrm{Fo}_{39}$, thereby suggesting that there is an overlap of olivine compositions between EZ and LVZ. A considerable overlap of olivine compositions in respect of different zones was also described from the Delakhari Sill (Sen 1980), which is located close to the present study area. The olivine compositions of the investigated lava flows are more Fe-rich than those of the 'three phenocryst basalts' $\left(\mathrm{Fo}_{85}\right)$ of the Deccan Traps (Krishnamurthy and Cox 1977), indicating relatively more differentiated and relatively evolved nature of the magma. 
- The analysed pyroxene compositions correspond to the 'Quad' field in the Q-J classificatory diagram; phenocrystal pyroxenes are diopsidic while their groundmass counterparts mostly correspond to augite. Mineral chemistry of pyroxene reveals the presence of both Ca-rich $\left(\mathrm{Wo}_{33.41}\right.$ $\left.\mathrm{En}_{39.66} \mathrm{Fs}_{26.93}-\mathrm{Wo}_{47.08} \mathrm{En}_{49.87} \mathrm{Fs}_{3.05}\right)$ and Ca-poor $\left(\mathrm{Wo}_{11.09} \mathrm{En}_{39.17} \mathrm{Fs}_{49.74}-\mathrm{Wo}_{31.4} \mathrm{En}_{33.85} \mathrm{Fs}_{34.76}\right)$ varieties of pyroxenes. The identical $\mathrm{Mg}$ number (0.99) of investigated pyroxene phenocrysts (table 2) indicates a distinctly uniform composition. Moreover, the phenocrystal pyroxenes are characterized by a significant enrichment in $\mathrm{TiO}_{2}$ (ranging from 10.5-14.7 wt\%) which is possibly due to the influence of high water pressure (Barberi et al 1971). High water pressure leads to enrichment of tschermark molecule $\left(\mathrm{CaAl}_{2} \mathrm{SiO}_{6}\right)$ in the pyroxene structure, which ultimately gives rise to high $\mathrm{Ti}$ content of the pyroxene (because of $\mathrm{R}^{2}+2 \mathrm{Si} \leftrightarrow \mathrm{Ti}^{4+}+2 \mathrm{Al}$ replacement).

- Electron microprobe analyses of investigated plagioclase indicate that the phenocrystal plagioclase are calcic $\left(\mathrm{An}_{52.7}-\mathrm{An}_{72.9}\right)$, whereas groundmass plagioclase are relatively sodic $\left(\mathrm{An}_{47.3^{-}}\right.$ $\mathrm{An}_{61.6}$ ). The plagioclase compositions (table 3) show a systematic increase of orthoclase content with decrease in An content and this phenomenon was earlier described from parts of western DVP (Melluso et al 1995). The anorthite content of phenocrystal plagioclase ranges from $\mathrm{An}_{52.7}-\mathrm{An}_{72.9}$ and is poorer in An than those of 'picrite basalts' $\left(A n_{74-88}\right)$ and the 'three phenocryst basalts' $\left(\mathrm{An}_{72-88}\right)$ of the Deccan Traps, but this obtained range is consistent with that of 'normal basalts' $\left(\mathrm{An}_{57-66}\right)$ of Deccan Traps (Krishnamurthy and Cox 1977).

- Opaque phases in the lava flows are represented by titano-magnetite, ilmenite and pyrophanite (Mn-rich ilmenite). Incidentally, pyrophanites have also been observed in Deccan lavas from western India (Melluso and Sethna 2011).

- Pyroxene thermometric method when applied for corresponding zones of investigated lava flows records temperatures ranging from $850^{\circ}$ to $1280^{\circ} \mathrm{C}$. This wide range of crystallization temperatures is corroborated to the presence of both Ca-rich and Ca-poor pyroxenes and similar observation has been recorded earlier for Mandla lavas (Shrivastava and Ahmad 2005). Geothermometric estimations evaluated on the basis of coexisting olivine-augite compositions yield temperatures ranging from $1040^{\circ}-1160^{\circ} \mathrm{C}$ for different lava flows. The vesicular nature of lava flows containing large amounts of volatile materials is responsible for the low temperature value while the high temperatures of lava flows can be attributed to high modal content of glass and opaque minerals (Ahmad and Shrivastava 2005; Shrivastava and Ahmad 2005).

\section{Acknowledgements}

The authors express their heartfelt thanks to Mr. Abhishek Saha, Senior Research Fellow, Department of Geology, University of Calcutta for his encouragement, wholehearted help during the field sessions and for rendering valuable suggestions during the preparation of this paper. SG, JR and MB thankfully acknowledge Mr. N Bhattacharyya for his help during the fieldwork. The authors are deeply indebted to the Head, Department of Geology, University of Calcutta for providing all laboratory facilities. SG and JR are grateful to the UGC-DRS authority [Project no: F. No. 550/9/DRS/2007 (SAP I)] for providing financial assistance for carrying out the field work. JR thankfully acknowledges the University of Vienna for providing a visiting researcher grant. The authors gratefully acknowledge valuable comments and suggestions from Dr H C Sheth and an anonymous reviewer which were of great help in improving the quality of the manuscript. The authors gratefully acknowledge Prof. Talat Ahmad, Associate Editor, for his valuable comments and fruitful suggestions.

\section{References}

Ahmad M and Shrivastava J P 2005 Iron-Titanium Oxide geothermometry and petrogenesis of lava flows and dykes from Mandla Lobe of the Eastern Deccan Volcanic Province, India; Gondwana Res. 7 563-577.

Alexander P O and Paul D K 1977 Geochemistry and strontium isotopic composition of basalts from the Eastern Deccan Volcanic Province; India Mineral. Mag. 41 $165-172$.

Allegre C J, Birck J L, Capmas F and Courtillot V 1999 Age of the Deccan Traps using ${ }^{187} \mathrm{Re}^{-187}$ Os systematics; Earth Planet. Sci. Lett. 170 197-204.

Anderson S W, Stofan E R, Smreker S E, Guest J E and Wood B 1999 Pulsed inflation of pahoehoe lava flows: Implications for flood basalt emplacement; Earth Planet. Sci. Lett. 168 7-18.

Baksi A K 1994 Geochronological studies on whole-rock basalts, Deccan Traps, India: Evaluation of the timing of volcanism relative to the $\mathrm{K}-\mathrm{T}$ boundary; Earth Planet. Sci. Lett. 121 43-56.

Barberi F, Bizouard H and Varet J 1971 Nature of the clinopyroxene and iron enrichment in Alkalic and Transitional Basaltic Magmas; Contrib. Mineral. Petrol. 33 93-107.

Beane J E, Turner C A, Hooper P R, Subbarao K V and Walsh J N 1986 Stratigraphy, composition and form of Deccan Basalts, Western Ghats, India; Bull. Volcanol. 48 61-83.

Beane J E and Hooper P R 1988 A note on the picrite basalts of the Western Ghats, Deccan Traps, India; Geol. Soc. India Memoir 10 117-133. 
Bondre N R, Duraiswami R A, Dole G, Phadnis V M and Kale V S 2000 Inflated pahoehoe lavas from Sangamner area of the western Deccan Volcanic Province; Curr. Sci. 78 1004-1007.

Bondre N R, Duraiswami R A and Dole G 2004 Morphology and emplacement of flows from the Deccan Volcanic Province; India. Bull. Volcanol. 66 29-45.

Bondre N R, Hart W K and Sheth H C 2006 Geology and geochemistry of the Sangamner mafic dike swarm, Western Deccan Volcanic Province, India: Implications for regional stratigraphy; J. Geol. 114 155-170.

Coffin M F and Eldholm O 1994 Large igneous provinces: Crustal structure, dimensions and external consequences; Rev. Geophys. 32 1-36.

Courtillot V, Feraud H, Maluski D, Moreau M G and Besse J 1988 Deccan flood basalts and the Cretaceous/Tertiary boundary; Nature 333 843-846.

Courtillot V and Renne P R 2003 On the ages of flood basalt events; Compt. Rend. Geosci. 335 113-140.

Cox K G and Mitchell C 1988 Importance of crystal settling in the differentiation of Deccan Trap basaltic magmas; Nature 333 447-449.

Cox K G and Hawkesworth C J 1984 Relative contribution of crust and mantle to flood basalt magmatism, Mahabaleshwar area, Deccan Traps; Phil. Trans. Roy. Soc. London A310 627-641.

Cox K G and Hawkesworth C J 1985 Geochemical stratigraphy of the Deccan Traps at Mahabaleshwar, Western Ghats, India, with implications for open system magmatic processes; J. Petrol. 26 355-377.

Craig J R, Sandhaus D J and Guy R E 1985 Pyrophanite $\mathrm{MnTiO}_{3}$ from Sterling Hill, New Jersey; Canad. Mineral. 23 491-494.

Crookshank H 1936 The Geology of the northern slopes of the Satpuras between the Morand and Sher rivers; Geol. Surv. India Memoir 66 218p.

Damasceno D, Scoates J S, Weis D, Frey F A and Giret A 2002 Mineral chemistry of mildly alkalic basalts from the 25 Ma Mont Crozier Section, Kerguelen Archipelago: Constraints on phenocryst crystallization environments; J. Petrol. 43 1389-1413.

De A 1972 Structural features of the Deccan Trap tholeiitic basalt flows of southern Kutch; Proc. Indian Science Congress 56th Session Pt. III, 180p.

De A 1974 Short and long distance correlation of Deccan Trap lava flows; Abstract Bull. Geol. Mining Metallur. Soc. India 47 50p.

De A 1996 Entablature structure in Deccan Trap flows: Its nature and probable mode of origin; Gond. Geol. Mag. 2 439-447.

Deer W A, Howie R A and Zussman J 1979 An introduction to the rock forming minerals; The English Language Book Society, $528 \mathrm{p}$.

Deshmukh S S, Sano T and Nair K K K 1996 Geology and chemical stratigraphy of the Deccan basalts of Chikaldara and Behramghat sections of the eastern part of the Deccan Trap province, India; Gond. Geol. Mag. 2 $1-22$.

Devey C W and Lightfoot P C 1986 Volcanological and tectonic control of stratigraphy and structure in the western Deccan traps; Bull. Volcanol. 48 195-207.

Dixon B E and Kennedy W Q 1933 Optically uniaxial titanaugite from Aberdeenshire; Z Krystallography $\mathbf{8 6}$ $112-120$.

Duncan R A and Pyle D G 1988 Rapid eruption of the Deccan flood basalts at the Cretaceous/Tertiary boundary; Nature 333 841-843.

Duraiswami R A, Bondre N R, Dole G, Phadnis V M and Kale V S 2001 Tumuli and associated features from the western Deccan volcanic province, India; Bull. Volcanol. 63 435-442.

Duraiswami R A, Bondre N R and Dole G 2002 Morphology and structure of flow-lobe tumuli from Pune and Dhule areas, western Deccan Volcanic Province; J. Geol. Soc. India 60 57-65.

Duraiswami R A, Bondre N R and Managave S 2008 Morphology of rubbly pahoehoe (simple) flows from the Deccan Volcanic Province: Implications for style of emplacement; J. Volcanol. Geotherm. Res. 177 822-836.

Eldholm O and Coffin M F 2000 Large igneous provinces; In: The history and dynamics of global plate motions (eds) Richards M A, Gordon R G and Vander Hilst R D, Am. Geophys. Union Mono. 121 309-326.

Ernst R E and Bell K 2010 Large Igneous Provinces (LIPs) and carbonatites; Mineral. Petrol. 98 55-76.

Fermor L L and Fox C S 1916 Deccan Trap flows of Linga; Geol. Surv. India Rec. 47 81-136.

Fleet M E, Mac Rae N D and Harzberg C T 1977 Partition of nickel between olivine and sulphide: A test for immiscible sulphide liquids; Contrib. Miner. Petrol. 65 191-198.

Furuyama K, Hari K R and Santosh M 2001 Crystallization history of Primitive Deccan Basalt from Pavagadh Hill, Gujarat, Western India; Gond. Res. 4 427-436.

Hon K, Kauahikaua J, Denlinger R and Mackay K 1994 Emplacement and inflation of pahoehoe sheet flows: Observations and measurements of active lava flows on Kilauea Volcano, Hawaii; Geol. Soc. Am. Bull. 106 351-370.

Kashyap M, Shrivastava J P and Kumar R 2010 Occurrence of small scale inflated pahoehoe lava flows in Mandla Lobe of the Eastern Deccan Volcanic Province; Curr. Sci. 98 72-76.

Keszthelyi L and Self S 1998 Some physical requirements for the emplacement of long basaltic lava flows; J. Geophys. Res. 103 27,447-27,464.

Keszthelyi L, Self S and Thordarson T 1999 Application of recent studies on the emplacement of basaltic lava flows to the Deccan Traps; In: Deccan Volcanic Province (ed.) Subbarao K V, Geol. Soc. India Memoir 43 485-520.

Krishnamurthy P and Cox K G 1977 Picrite basalts and related lavas from the Deccan Traps of Western India; Contrib. Mineral. Petrol. 62 53-75.

Lindsley D H 1983 Pyroxene thermometry; Am. Mineral. 68 477-493.

Loucks R R 1996 A precise olivine-augite Mg-Fe exchange geothermometer; Contrib. Mineral. Petrol. 125 140-150.

Mahoney J J and Coffin M F 1997 Large igneous provinces: Continental, oceanic and planetary flood volcanism; $\mathrm{Am}$. Geophys. Union Mono. 100 438p.

Mahoney J J, Macdougall J D, Lugmair G W, Gopalan K and Krishnamurthy P 1982 Origin of the Deccan Trap flows at Mahabaleshwar inferred from $\mathrm{Nd}$ and $\mathrm{Sr}$ isotopic and chemical evidence; Earth Planet. Sci. Lett. 60 $47-60$.

Mahoney J J, Sheth H, Chandrashekharam D and Peng Z X 2000 Geochemistry of flood basalts of the Toranmal section, Northern Deccan Traps, India: Implications for regional Deccan stratigraphy; J. Petrol. 41 1099-1120.

Melluso L, Beccaluva L, Brotzu P, Gregnanin A, Gupta A K, Morbidelli L and Traversa G 1995 Constraints on the mantle sources of the Deccan Traps from the petrology and geochemistry of the basalts of Gujarat state (western India); J. Petrol. 36 1393-1432.

Melluso L, Gennaro R D and Rocco I 2010 Compositional variations of chromiferous spinel in Mg-rich rocks of the Deccan Traps, India; J. Earth Syst. Sci. 119(3) 343-363. Melluso L and Sethna S F 2011 Mineral compositions in the Deccan Igneous Rocks of India: An overview; In: Topics 
in igneous petrology (eds) Ray J, Sen G and Ghosh B (Heidelberg: Springer), pp. 135-159.

Morimoto N 1989 Nomenclature of pyroxenes; Canad. Mineral. 27 143-156.

Morimoto N, Fabries J, Ferguson A K, Ginzburg I V, Ross M, Seifert F A and Zussman J 1988 Nomenclature of pyroxenes; Am. Mineral. 73 1123-1133.

Nair K K K, Chatterjee A K and Sano T 1996 Stratigraphy and geochemistry of the Deccan basalts along Toranmal section, western Satpura region; Deccan Basalts (eds) Deshmukh S S and Nair K K K, Gond. Geol. Mag. 2 23-48.

Nielsen C H and Sigurdsson H 1981 Quantitative methods for electron microprobe analysis of sodium in natural and synthetic glasses; Am. Mineral. 66 547-552.

Pande K 2002 Age and duration of the Deccan Traps, India: A review of radiometric and palaeomagnetic constrains; J. Earth Syst. Sci. 111 115-123.

Pattanayak S K and Shrivastava J P 1996a Petrography and major oxide geochemistry of basalts from Eastern Deccan Volcanic Province, India: A stratigraphic model; Deccan 1996, Geol. Soc. India 20.

Pattanayak S K and Shrivastava J P 1996b Petrominerography and major oxide geochemical variations in the basaltic lava flow sequence from Eastern Deccan Volcanic Province, India: A stratigraphy and genetic model; Gond. Geol. Mag. 2537.

Pattanayak S K and Shrivastava J P 1999 Petrography and major-oxide geochemistry of basalts from the Eastern Deccan Volcanic Province, India; J. Geol. Soc. India Memoir 43 233-270.

Peck D L and Minakami T 1968 The formation of columnar joints in the upper part of Kilauean Lava Lakes, Hawaii; Bull. Geol. Soc. Am. 167 641-644.

Peng Z X, Mahoney J J, Hooper P R, MacDougall J D and Krishnamurthy P 1998 Basalts of the northeastern Deccan Traps, India: Isotopic and elemental geochemistry and relation to southwestern Deccan Trap stratigraphy; J. Geophys. Res. 103 29,843-29,865.

Philpotts A R and Ague 2009 Principles of igneous and metamorphic petrology; (New York: Cambridge University Press), p. 57.

Pouchou J and Pichoir F 1991 Quantitative analysis of homogeneous or stratified microvolumes applying the model 'PAP'; In: Electron probe quantitation (eds) Heinrich K F J and Newbury D E, (New York: Plenum), pp. 31-75.

Self S, Thordarson T and Keszthelyi L 1997 Emplacement of continental flood basalt lava flows; In: Large Igneous Provinces: Continental, Oceanic and Planetary Flood Volcanism (eds) Mahoney J J and Coffin M F, Am. Geophys. Union Mono. 100 381-410.

Self S, Keszthelyi L and Thordarson T 1998 The importance of pahoehoe; Ann. Rev. Earth Planet. Sci. 26 81-110.

Sen G 1980 Mineralogical variations in the Delakhari Sill, Deccan Trap Intrusion, Central India; Contrib. Mineral. Petrol. 75 71-78.

Sen G 2001 Generation of Deccan Trap magmas; J. Earth Syst. Sci. 110 409-431.
Sen G and Chandrasekharam D 2011 Deccan Traps Flood Basalt Province: An evaluation of the thermochemical plume model; In: Topics in igneous petrology (eds) Ray J, Sen G and Ghosh B (Heidelberg: Springer), pp. 29-53.

Sengupta P and Ray J 2007 Mineral chemistry of basaltic lava flows from Narsingpur-Harrai-AmarwaraLakhnadon areas of Eastern Deccan, Central India; In: Igneous petrology: 21st century perspective (eds) Ray $\mathrm{J}$ and Bhattacharyya C (New Delhi: Allied Publishers), pp. 37-72.

Sengupta P and Ray J 2011 Petrogenesis of Flood Basalts of the Narsingpur-Harrai-Amarwara-Laknadon section of Eastern Deccan Province, India; In: Topics in igneous petrology (eds) Ray J, Sen G and Ghosh B (Heidelberg: Springer), pp. 191-238.

Sheth H C 2006 The emplacement of pahoehoe lavas on Kilauea and in the Deccan Traps; J. Earth Syst. Sci. 115 615-629.

Sheth H C 2007 'Large Igneous Provinces (LIPs)': Definition, recommended terminology, and a hierarchical classification; Earth Sci. Rev. 85 117-124.

Sheth H C, Ray J S, Ray R, Vanderkluysen L, Mahoney J J, Kumar A, Shukla A D, Das P, Adhikari S and Jana B 2009 Geology and geochemistry of Panchmarhi dykes and sills, Satpura Gondwana Basin, central India: Problems of dyke-sill-flow correlations in the Deccan Traps; Contrib. Mineral. Petrol. 158 357-380.

Sheth H C, Ray J S, Senthil Kumar P, Duraiswami R A, Chatterjee R N and Gurav T 2011 Recycling of Flow-Top Breccia Crusts into molten interiors of flood basalt lava flows: Field and geochemical evidence from the Deccan Traps; In: Topics in igneous petrology (eds) Ray J, Sen G and Ghosh B (Heidelberg: Springer), pp. 161-180.

Shrivastava J P and Ahmad M 2005 A review of research on Late Cretaceous volcanic-sedimentary sequences of the Mandla Lobe: Implications for Deccan volcanism and the Cretaceous/Palaeogene boundary; Cret. Res. 26 145-156.

Simkin T and Smith J V 1970 Minor-element distribution in olivine; J. Geol. 78 304-325.

Spray J G and Rae D A 1995 Quantitative electronmicroprobe analysis of alkali silicate glasses: A review and user guide; Canad. Mineral. 33 323-332.

Subbarao K V and Hooper P R 1988 Reconnaissance map of the Deccan Basalt Group in the Western Ghats, India; In: Deccan Flood Basalts (ed.) Subbarao K V, Geol. Soc. India Memoir 10.

Tracy R J and Robinson P 1977 Zoned titanian augite in alkali olivine basalt from Tahiti and the nature of titanium substitutions in augite; Am. Mineral. 62 634-645.

Venkatesan T R, Pande K and Gopalon G 1993 Did Deccan volcanism predate the Cretaceous/Tertiary transition?; Earth Planet. Sci. Lett. 119 181-189.

West W D 1958 The petrography and petrogenesis of forty eight flows of Deccan Traps penetrated by borings in western India; Trans. Ind. Natl. Inst. Sci. 4 1-56.

Yedekar D B, Aramaki S, Fujii T and Sano T 1996 Geochemical signature and stratigraphy of the ChhindwaraMandla sector of the Eastern Deccan Volcanic Province and problems of its correlation; Gond. Geol. Mag. 2 49-68. 